University of Nebraska - Lincoln

DigitalCommons@University of Nebraska - Lincoln

\title{
Clinical Experience and Sexual Function Outcome of Patients With Priapism Treated With Penile Cavernosal-Dorsal Vein Shunt Using Saphenous Vein Graft
}

\author{
Rei K. Chiou \\ Creighton University Medical Center, chiou@creighton.edu \\ Himanshu Aggarwal \\ Duke University Medical Center, himanshu.aggarwal@duke.edu \\ Adam C. Mues \\ University of Nebraska College of Medicine \\ Christopher R. Chiou \\ Creighton University Medical Center \\ Fleur L. Broughton \\ Department of Veterans Affairs Nebraska Western lowa Healthcare System
}

Follow this and additional works at: https://digitalcommons.unl.edu/veterans

Chiou, Rei K.; Aggarwal, Himanshu; Mues, Adam C.; Chiou, Christopher R.; and Broughton, Fleur L., "Clinical Experience and Sexual Function Outcome of Patients With Priapism Treated With Penile Cavernosal-Dorsal Vein Shunt Using Saphenous Vein Graft" (2009). U.S. Department of Veterans Affairs Staff Publications. 31.

https://digitalcommons.unl.edu/veterans/31

This Article is brought to you for free and open access by the U.S. Department of Veterans Affairs at DigitalCommons@University of Nebraska - Lincoln. It has been accepted for inclusion in U.S. Department of Veterans Affairs Staff Publications by an authorized administrator of DigitalCommons@University of Nebraska - Lincoln. 


\title{
Clinical Experience and Sexual Function Outcome of Patients With Priapism Treated With Penile Cavernosal-Dorsal Vein Shunt Using Saphenous Vein Graft
}

\author{
Rei K. Chiou, Himanshu Aggarwal, Adam C. Mues, Christopher R. Chiou, \\ and Fleur L. Broughton
}

OBJECTIVES To assess the outcome of new penile cavernosal-dorsal vein shunt using a saphenous vein graft. Traditional surgeries for priapism have high failure rate and subsequent impotence.

METHODS

We reviewed the medical records of, and administered a questionnaire and the International Index of Erectile Function to, 16 consecutive patients with priapism who had treated with the penile cavernosal-dorsal vein shunt from 1997 to 2007. Their age was 15-65 years. The duration of ischemic priapism was 32 hours to 8 days. Ten patients had previously undergone shunt surgery by other urologists. Of the 16 patients, 5 returned the questionnaires.

RESULTS

Priapism resolved or was improved after surgery in all 16 patients. One patient was lost to follow-up. One pediatric patient was excluded from the analysis. One patient with nonischemic priapism continued to have sexual intercourse. Of the 13 adult patients with ischemic priapism and follow-up for $\leq 6.5$ years, 3 patients had no erection, 1 had very little erection, and 9 (69\%) had erection. Of the 9 patients with erections possible, six had had sexual intercourse (International Index of Erectile Function score 32-70) and 3 had not; 1 had a mental disorder, 1 was in prison, and for 1 , the reason was unknown. After surgery, color Doppler ultrasound studies showed a patent shunt in all patients and restoration of cavernosal arterial flow in 12 of 13 patients studied.

CONCLUSIONS A penile cavernosal-dorsal shunt appears effective for priapism. It resulted in priapism resolution even in patients who had experienced a previous failed cavernosal-glandular shunt or cavernosalspongiosal shunt, with a high rate of sexual function preservation. UROLOGY 73: 556-561, 2009. (C) 2009 Elsevier Inc.

$\mathrm{P}$ riapism is a urologic emergency. It is traditionally divided into ischemic (low-flow) and nonischemic (high-flow) priapism, with each requiring different management strategies. The management goal of ischemic priapism is to achieve detumescence and preserve as much erectile function as possible. The initial treatment for ischemic priapism is usually aspiration and intracavernous injection of sympathomimetic drugs with or without irrigation. If this fails to resolve the priapism, some form of cavernosal-glandular shunt (Winter or AlGhorab shunt) is commonly performed. Proximal shunting procedures using the Quackels (cavernosal-spongiosal) or Grayhack (cavernosal-saphenous vein) technique are per- formed when distal shunting procedures have failed to resolve the priapism. The efficacy of shunting procedures in resolving priapism and the outcome of preserving erectile function have varied among reports. Some investigators have reported very disappointing outcomes using commonly performed shunting procedures. ${ }^{1}$ We have previously reported on a new surgical technique involving the saphenous vein graft and the penile cavernosaldorsal vein $(C D)$ shunt. ${ }^{2,3}$ In the present study, we have reviewed our clinical experience of treating 16 patients with priapism using this new shunt procedure and examined the sexual function outcome of these patients.

\section{MATERIAL AND METHODS}

From the Division of Urology, Creighton University Medical Center and University of Nebraska Medical Center; and Division of Urology, Department of Veterans Affairs Nebraska Western Iowa Healthcare System, Omaha, Nebraska

Reprint requests: Rei K. Chiou, M.D., Ph.D., Division of Urology, Creighton University Medical Center, 601 North 30th Street, Suite 3700, Omaha, NE 68131.

E-mail: chiou@creighton.edu

Submitted: June 18, 2008, accepted (with revisions): October 3, 2008
We performed a retrospective chart review of 16 consecutive patients with priapism who were treated with a penile CD shunt from July 1997 to December 2007 (Table 1). In addition to documenting the review, we administered by mail the Interna- 


\begin{tabular}{|c|c|c|c|c|c|c|}
\hline $\begin{array}{l}\text { Pt. } \\
\text { No. }\end{array}$ & $\begin{array}{l}\text { Age } \\
\text { (y) }\end{array}$ & Cause & $\begin{array}{l}\text { Duration } \\
\text { Before CD } \\
\text { Shunt }\end{array}$ & $\begin{array}{l}\text { Previous } \\
\text { Treatment }\end{array}$ & Outcome After CD Shunt & Follow-up \\
\hline 1 & 45 & Idiopathic & $32 \mathrm{~h}$ & $\begin{array}{l}\text { Asp/IPT, Winter } \\
\text { shunt }\end{array}$ & $\begin{array}{l}\text { Priapism resolved, has erection, } \\
\text { sex, IIEF score } 60 \text { (Q1-5, Q2- } \\
\text { 5, Q3-5, Q4-5, Q5-5*) }\end{array}$ & $1 \mathrm{y}$ \\
\hline 2 & 45 & Idiopathic & $2 d$ & $\begin{array}{l}\text { Asp/IPT, Winter } \\
\text { shunt }\end{array}$ & $\begin{array}{l}\text { Priapism resolved, induration } \\
\text { present, little erection, no sex }\end{array}$ & $4 \mathrm{mo}$ \\
\hline 3 & 31 & Idiopathic & $2 d$ & Asp/IPT & $\begin{array}{l}\text { Priapism resolved, mental } \\
\text { retardation, erection, no sex }\end{array}$ & $3 \mathrm{y}, 9 \mathrm{mo}$ \\
\hline 4 & 15 & $\begin{array}{l}\text { Sickle } \\
\quad \text { cell disease }\end{array}$ & $3 d$ & Asp/IPT & Priapism resolved & $5 \mathrm{mo}$ \\
\hline 5 & 65 & Idiopathic & $3 d$ & Asp/IPT & $\begin{array}{l}\text { Priapism resolved, patient in } \\
\text { prison, erection, no sex }\end{array}$ & $14 \mathrm{mo}$ \\
\hline 6 & 30 & Idiopathic & $3 d$ & $\begin{array}{l}\text { Asp/IPT, Al- } \\
\text { Ghorab shunt }\end{array}$ & $\begin{array}{l}\text { Priapism resolved, erection, } \\
\text { sex, IIEF score } 70 \text { (Q1-5, } \\
\text { Q2-5, Q3-5, Q4-5, Q5-5) }\end{array}$ & $3 \mathrm{mo}$ \\
\hline 7 & 57 & Trazodone & $3 d$ & $\begin{array}{l}\text { Asp/IPT, Winter } \\
\text { shunt }\end{array}$ & Priapism resolved, no erection & $3 \mathrm{mo}$ \\
\hline 8 & 49 & Idiopathic & $4 d$ & $\begin{array}{l}\text { Asp/IPT, Winter } \\
\text { shunt }\end{array}$ & $\begin{array}{l}\text { Priapism resolved, erection, sex } \\
\text { using constriction band, IIEF } \\
\text { score } 63 \text { (Q1-4, Q2-4, Q3-4, } \\
\text { Q4-4, Q5-4) }\end{array}$ & $6 \mathrm{y}, 5 \mathrm{mo}$ \\
\hline 9 & 36 & $\begin{array}{l}\text { Chronic myeloid } \\
\text { leukemia }\end{array}$ & $4 d$ & $\begin{array}{l}\text { Asp/IPT, Al- } \\
\text { Ghorab shunt }\end{array}$ & Priapism resolved & Lost \\
\hline 10 & 44 & Idiopathic & $4.5 d$ & $\begin{array}{l}\text { Asp/IPT, Winter } \\
\text { shunt }\end{array}$ & $\begin{array}{l}\text { Priapism improved, erection, } \\
\text { uses Viagra for sex, IIEF } \\
\text { score } 35 \text { (Q1-5, Q2-1, Q3-1, } \\
\text { Q4-1, Q5-1) }\end{array}$ & $10 \mathrm{mo}$ \\
\hline 11 & 36 & Idiopathic & $5 d$ & $\begin{array}{l}\text { Asp/IPT, } \\
\text { Winter, } \\
\text { Quackel } \\
\text { shunts }\end{array}$ & $\begin{array}{l}\text { Priapism resolved, erection, } \\
\text { sex, IIEF score } 32 \text { (Q1-1, } \\
\text { Q2-1, Q3-1, Q4-1, Q5-1) }\end{array}$ & $1 \mathrm{y}$ \\
\hline 12 & 48 & Trazodone & $6 d$ & $\begin{array}{l}\text { Asp/IPT, Winter } \\
\text { shunt }\end{array}$ & Priapism resolved, no erection & $1 \mathrm{y}, 4 \mathrm{mo}$ \\
\hline 13 & 41 & $\begin{array}{l}\text { Psychiatric } \\
\text { medication }\end{array}$ & $6 d$ & Asp/IPT & $\begin{array}{l}\text { Priapism resolved, erection, } \\
\text { sex, difficultly penetrating }\end{array}$ & $7 \mathrm{mo}$ \\
\hline 14 & 25 & $\begin{array}{l}\text { Chronic renal } \\
\text { failure }\end{array}$ & $1 \mathrm{wk}$ & $\begin{array}{l}\text { Asp/IPT, Winter } \\
\text { shunt }\end{array}$ & Priapism resolved, no erection & $1 \mathrm{mo}$ \\
\hline 15 & 25 & Idiopathic & $8 d$ & Sudafed & $\begin{array}{l}\text { Priapism resolved, erection, had } \\
\text { not yet attempted sex }\end{array}$ & $3 \mathrm{mo}$ \\
\hline 16 & 33 & Trauma & $3 w k$ & $\begin{array}{c}\text { Terbutaline, } \\
\text { Asp/IPT }\end{array}$ & $\begin{array}{l}\text { Arteriogenic priapism resolved, } \\
\text { potent, sex, arteriosinusoidal } \\
\text { malformation closed after } 7 \mathrm{y}\end{array}$ & $7.5 y$ \\
\hline
\end{tabular}

CD, cavernosal-dorsal vein; Asp/IPT, aspiration and intracavernosal pharmacotherapy therapy; IIEF, International Index of Erectile Function; Q, question.

* Erection-related IIEF questions. Q1, how often were you able to get an erection during sexual activity; Q2, when you had erections with sexual stimulation, how often were your erections hard enough for penetration; Q3, when you attempted sexual intercourse, how often were you able to penetrate (enter) your partner; Q4, during sexual intercourse, how often were you able to maintain your erection after you had penetrated (entered) your partner; Q5, during sexual intercourse, how difficult was it to maintain your erection to completion of intercourse (each with scale of 0-5).

tional Index of Erectile Function and a questionnaire assessing the degree of spontaneous erection, information about supplemental measures to obtain or enhance erection, recurrent episodes of priapism, and more necessary surgical procedures. ${ }^{4}$ All saphenous vein graft penile CD shunt procedures were performed by an experienced urologist (R.K.C.). The age of patients was 15-65 years. One patient was a boy with sickle cell disease. The age of the adult patients was 21-65 years. The causes of priapism were idiopathic in 9 patients, antidepressant or other psychiatric medication in 3 patients, and trauma, sickle cell disease, chronic myeloblastic leukemia, and chronic renal failure in 1 patient each. One patient had developed traumatic high-flow priapism of 3 weeks' duration before surgery, and the other 15 patients had had ischemic priapism for 32 hours to 8 days (mean duration 4.1 days). In the 15 patients with ischemic priapism, previous treatment consisting of aspiration with intracavernosal pharmacotherapy had failed. Ten patients were initially treated by other urologists with common surgical interventions before they were referred to us. Of these 10 patients, 9 had a failed cavernosal-glandular (Winter or Al-Ghorab) shunt and 1 had a failed Winter shunt and cavernosal-spongiosal (Quackels) shunt.

Color Doppler ultrasound (CDU) studies were performed in the 15 patients before penile CD shunt surgery. With the penis gently placed toward the abdomen, and the transducer placed at the ventral surface of the penis, we examined the cavernosal arterial blood flow of the proximal and mid-penile shafts and measured the hemodynamic parameters, including the peak 


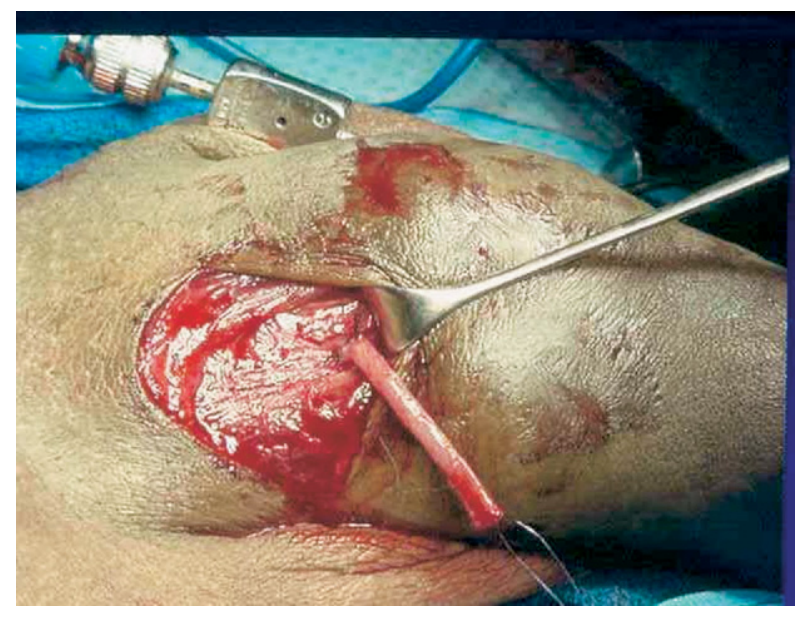

Figure 1. Penile cavernosal-dorsal vein shunt using saphenous vein graft. Upper end of saphenous vein graft anastomosed to deep dorsal vein.

systolic velocity (PSV), end-diastolic velocity, and resistive index. ${ }^{5}$ In patients with perineal trauma, we also placed the transducer at the perineum to examine the cavernosal arteries at the crura. After surgery, $20 \mathrm{CDU}$ studies were completed in 13 patients.

The surgical technique of the penile CD shunt has been previously described. ${ }^{2,3}$ In brief, an oblique incision was made at the base of the penis to identify the dorsal vein and expose the corpora. A 2.5-3-cm segment of the saphenous vein was then harvested from the lower leg, and an anastomosis was created with the cephalad end of the saphenous vein graft connecting to the dorsal vein and the caudal end connecting to a proximal corporal window using 4-0 or 5-0 Prolene suture (Fig. 1 and Fig. 2).

\section{RESULTS}

In all 16 patients, the priapism resolved or was improved after penile CD shunt placement. No additional procedures were required in these patients. The CDU studies, before penile CD shunt surgery, showed no detectible cavernosal arterial flow at the proximal penile shaft in 13 of 15 patients studied. This indicated that their previous therapeutic interventions had not relieved the venoocclusive mechanism. In 1 patient, cavernosal arterial flow was present, but it appeared to stop at the area of the proximal to mid-penile shaft junction. In this patient, we noted an arterial branch from the proximal corpus cavernosum to the corpus spongiosum. This anatomic variation might have been responsible for maintenance of the blood flow at the proximal penile shaft. In 1 patient, who developed priapism after perineal trauma, the CDU study showed an arteriosinusoidal malformation at the crura, with a high PSV of $30.9 \mathrm{~cm} / \mathrm{s}$, indicating an arteriogenic origin of the priapism. The CDU studies after surgery showed the presence of blood flow in the CD shunt, indicating its patency in all 13 patients studied. Relief of the veno-occlusive status and restoration of the cavernosal arterial blood flow were observed in 12 of the 13 patients studied. The postoperative cavernosal arterial PSV varied among patients. One patient had resolution

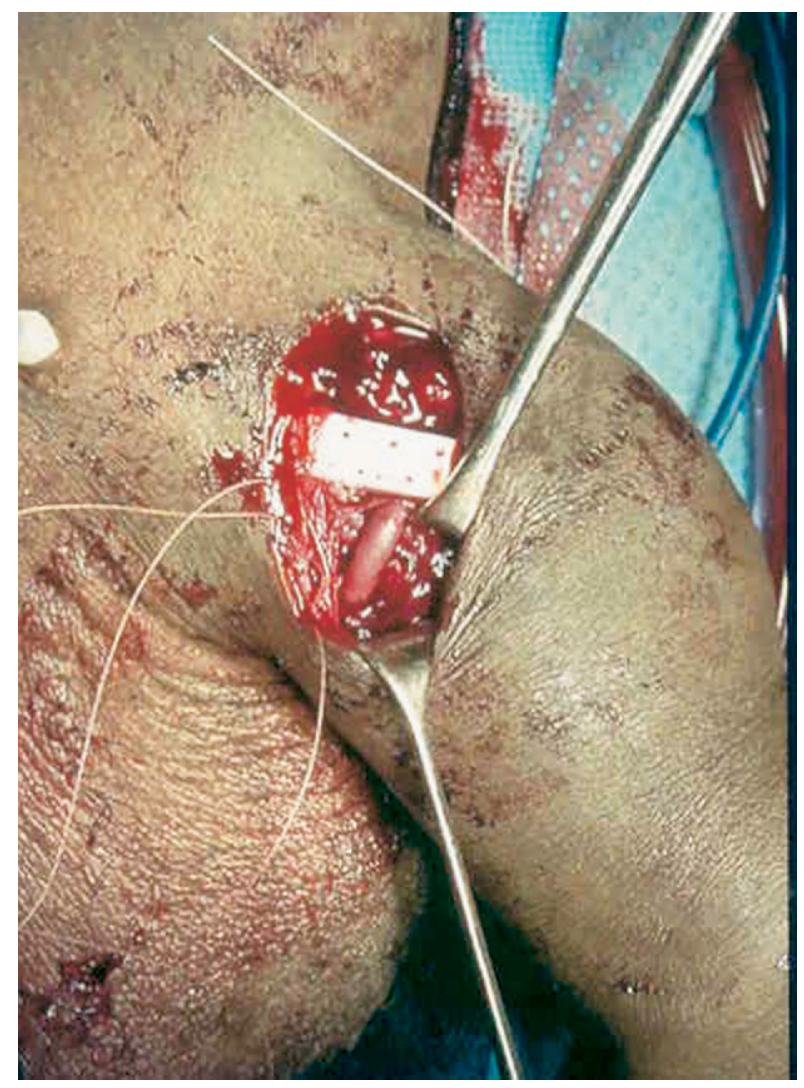

Figure 2. Completion of penile cavernosal-dorsal vein shunt with lower end of saphenous vein graft anastomosed to corpora window.

of priapism and transient cavernosal arterial flow restoration; however, subsequent CDU studies showed no detectible cavernosal arterial blood flow despite the presence of a patent shunt. Some patients appeared to have postischemic hyperemia, with a PSV of $\leq 27.3 \mathrm{~cm} / \mathrm{s}$ (see Table 2). In 1 patient with arteriogenic priapism, the CDU studies, after placement of a penile CD shunt, showed improvement in priapism hemodynamics, with persistence of the arteriosinusoidal malformation during short-term follow-up. After 7.5 years, at the long-term follow-up examination, spontaneous closure of the arteriosinusoidal malformation was noted on the CDU study.

One patient did not return to the clinic for follow-up after discharge and also did not return the questionnaires. The other 15 patients had been followed up after penile CD shunt surgery, with follow-up of 1 month to 7.5 years. One pediatric patient was excluded from the sexual function outcome analysis. Of the 13 adult patients with low-flow priapism, 3 indicated a complete lack of erections during follow-up and 1 had very little erection. The other 9 patients $(69 \%)$ reported having spontaneous erections after penile CD shunt surgery. Of the 9 patients with erections, 6 had sexual intercourse after surgery. Of these 6 patients, 3 had an International Index of Erectile Function score of $\geq 60$ and 2 had a score of $\leq 35$ (Table $1)$. The last patient did not provide an International Index of Erectile Function score but indicated that he 


\begin{tabular}{|c|c|c|c|c|c|c|}
\hline \multirow{2}{*}{$\begin{array}{l}\text { Pt. } \\
\text { No. }\end{array}$} & \multicolumn{3}{|c|}{ CDU Before CD Shunt } & \multicolumn{3}{|c|}{ CDU After CD Shunt } \\
\hline & PSV (cm/s) & $\operatorname{EDV}(\mathrm{cm} / \mathrm{s})$ & RI & PSV $(\mathrm{cm} / \mathrm{s})$ & $\operatorname{EDV}(\mathrm{cm} / \mathrm{s})$ & $\mathrm{RI}$ \\
\hline 1 & No flow & No flow & - & $20.1(1 \mathrm{~h})$, shunt patent & 0.0 & 1.0 \\
\hline \multirow[t]{3}{*}{2} & No flow & No flow & - & 8.29 (1 h), shunt patent & -2.13 & 1.26 \\
\hline & & & & No flow (1 d), shunt patent & No flow & No flow \\
\hline & & & & No flow (3 d), shunt patent & No flow & No flow \\
\hline 3 & No flow & No flow & - & $20.0(2 \mathrm{~d})$, shunt patent & 5.0 & 0.7 \\
\hline 4 & No flow & No flow & - & 3.57 (11 d), shunt patent & 0.0 & 1.0 \\
\hline 5 & No flow & No flow & - & 7.55 (10 d), shunt patent & 2.61 & 0.65 \\
\hline \multirow[t]{2}{*}{6} & No flow & No flow & - & $21.3(2 \mathrm{~d})$, shunt patent & 5.32 & 0.75 \\
\hline & & & & 7.0 (1 mo), shunt patent & 0.0 & 1.0 \\
\hline \multirow[t]{2}{*}{7} & No flow & No flow & - & $3.0(1 \mathrm{~d})$, shunt patent & - & - \\
\hline & & & & $\begin{array}{l}\text { Flow present, PSV not measured } \\
\text { (3 wk), shunt patent }\end{array}$ & - & - \\
\hline 8 & 11.0 & -2.0 & 1.2 & $7.0(15 \mathrm{~d})$, shunt patent & 1.22 & 0.8 \\
\hline 9 & No flow & No flow & - & - & - & - \\
\hline 10 & - & - & - & No flow (3 d), shunt patent & No flow (3 d), shunt patent & - \\
\hline 11 & No flow & No flow & - & $27.3(4 \mathrm{~d})$, shunt patent & 3.19 & 0.88 \\
\hline 12 & No flow & No flow & - & - & - & - \\
\hline 13 & No flow & No flow & - & $\begin{array}{l}\text { Flow present, PSV not measured } \\
(1 \mathrm{~h}) \text {, shunt patent }\end{array}$ & $\begin{array}{l}\text { Flow present, PSV not } \\
\text { measured }(1 \mathrm{~h}) \text {, shunt } \\
\text { patent }\end{array}$ & - \\
\hline 14 & No flow & No flow & - & - & - & - \\
\hline \multirow[t]{2}{*}{15} & No flow & No flow & - & $10.3(1 \mathrm{~d})$, shunt patent & 2.33 & 0.8 \\
\hline & & & & $6.04(9 \mathrm{~d})$, shunt patent & 3.02 & 0.5 \\
\hline \multirow[t]{3}{*}{16} & $\begin{array}{l}\text { 30.9, prominent } \\
\text { arteriosinusoidal } \\
\text { malformation }\end{array}$ & -3.69 & 1.12 & $\begin{array}{l}13.6(40 \mathrm{~d}) \text {, shunt patent, } \\
\text { persistent arteriosinusoidal } \\
\text { malformation }\end{array}$ & 4.03 & 0.7 \\
\hline & & & & $\begin{array}{l}13.8 \text { ( } 3 \mathrm{mo}) \text {, shunt patent } \\
\text { persistent arteriosinusoidal } \\
\text { malformation }\end{array}$ & -2.98 & 1.22 \\
\hline & & & & $\begin{array}{l}15(7.5 \mathrm{y}), \mathrm{n} \text { flow in shunt, no } \\
\text { arteriosinusoidal malformation }\end{array}$ & 0.0 & 1.0 \\
\hline
\end{tabular}

CDU, color Doppler ultrasonography; PSV, peak systolic velocity; EDV, end-diastolic velocity; RI, resistive index; other abbreviations as in Table 1.

had sexual intercourse with only a partial erection and difficulty penetrating. One patient indicated satisfactory sexual function but needed to use a constriction band periodically. Another patient used Viagra. Finally, 3 of the 9 patients with erections did not have sexual intercourse. Of these 3 patients, 1 indicated having good erections, but was in prison and could not engage in sexual intercourse. Another patient experienced spontaneous erections but was mentally retarded and did not engage in sexual activity. Another patient had erections, but he did not try to have sexual intercourse for unknown reasons. All 4 patients who had high cavernosal arterial flow (PSV $\geq 20 \mathrm{~cm} / \mathrm{s}$ ) after surgery had erections during follow-up, despite the duration of priapism ( $\leq 8$ days; Tables 1 and 2 ).

One patient with perineal trauma-related high flow (arteriogenic) priapism continued to have periodic erections after surgery. He indicated that the periodic erections were much less troublesome then before surgery, and he was able to have sexual intercourse for $>7$ years after penile $\mathrm{CD}$ shunt placement. He developed erectile dysfunction a few months before his 7.5-year follow-up visit. The timing of the erectile dysfunction appeared to correlate with the spontaneous closure of the arteriosinusoidal malformation.

\section{COMMENT}

Ischemic priapism is a urologic emergency that requires prompt diagnosis and effective treatment. Stagnant blood in the corpora leads to deprivation of oxygen and an increase in carbon dioxide, which causes erectile tissue dysfunction, thrombosis, and, eventually, fibrosis of the erectile tissues, resulting in erectile dysfunction. ${ }^{6}$ Evacuation of the trapped blood by providing effective drainage of the corpora and restoring cavernosal blood flow are important to the preservation of erectile function. Although many patients with priapism of a relative short duration can be successfully treated with penile aspiration and intracavernosal pharmacotherapy using sympathomimetic drugs, patients who do not respond to such treatment usually require some type of shunting procedure to divert the corporeal blood. Lue and Tanagho et al. ${ }^{7}$ recommended that priapism of $<24$ hours' duration be treated with aspiration or intracorporeal pharmacotherapy and priapism lasting $>24$ hours be treated with a shunting procedure.

Various shunting procedures have been described. Although it is a common practice to use a Winter shunt or another modified cavernosal-glandular shunt for the initial treatment of priapism in patients who have not 
responded to penile aspiration and intracavernosal pharmacotherapy, Nixon et al. ${ }^{1}$ reported that $86 \%$ of their patients treated with a Winter shunt required a second shunt procedure. This seriously questions the effectiveness of a Winter shunt. ${ }^{1}$ Lue and Pescatori ${ }^{8}$ described a $\mathrm{T}$-shunt as a new form of cavernosal-glandular shunt. The potency outcome of patients treated with this technique is still not clear. Grayhack et al. ${ }^{9}$ described a corpus-saphenous vein shunt as connecting the caudal end of the dissected saphenous vein to the corpus cavernosum. Even though subsequent reports have indicated that this approach is effective in relieving priapism, cases of pulmonary embolism have been reported. This probably resulted from thrombosis of the shunt extending into the saphenofemoral junction, which caused deep femoral thrombosis. ${ }^{10}$

We have previously described our technique of a penile $C D$ shunt. Instead of dissecting the saphenous vein at the thigh, we use a segment of the saphenous vein at the ankle as a free graft to create a shunt from the proximal corpora to the dorsal vein of the penis. The harvest of the saphenous vein at the ankle is simple and requires only a small incision $(2-2.5 \mathrm{~cm})$. Furthermore, the creation of the penile CD shunt requires only a small $(2.5-\mathrm{cm})$ incision at the base of penis. The advantages of the penile CD shunt, compared with the Grayhack procedure, include a short and more direct course of drainage to the pelvic veins, easy dissection of the saphenous vein at the ankle, and smaller incisions. Compared with the cavernosal-spongiosal (Quackels) shunt, the penile CD shunt has the advantage of not requiring urethral dissection, avoiding the potential problem of causing the development of a urethrocavernous fistula or urethral stricture. $^{11,12}$ In addition, the penile $\mathrm{CD}$ vein shunt can be easily accessed for ligation, if necessary. In contrast, the cavernosal-spongiosal (Quackels) shunt is not amenable to surgical closure.

In our experience, several patients in whom an initial cavernosal-glandular shunt procedure failed will respond well to the penile CD shunt. This outcome is likely because although thrombosis of the distal corpora had occurred, adequate blood flow and viable cavernosal tissue were still present at the proximal corpora. In 1 patient, we noted improvement in the priapism and resolution of pain with placement of a penile CD shunt after a failed proximal cavernosal-spongiosal shunt. We believe this might have resulted from the advantage of a larger caliber of saphenous vein drainage with the $C D$ shunt. Conversely, spongiosal tissue might be more susceptible to thrombosis.

The selection of an appropriate shunting procedure might have an affect on the preservation of erectile capacity. If we find clinical indications for distal corporal fibrosis, we do not use the cavernosal-glandular (Winter/ Al-Ghorab) shunts. For example, if we observed at penile aspiration that the proximal penile shaft became soft but the distal penile shaft remained hard, it would be likely that the distal corpora had thrombosed and it would had been more appropriate to proceed with a proximal shunt rather than to perform a cavernosal-glandular shunt for these patients. Both the proximal and distal penile shaft shunts are designed to drain the blood for the whole cavernosal body. However, the shunt created at the thrombosed portion probably could not effectively drain the blood from other portions of the corpus cavernosum.

We have determined that using CDU for various stages of the management of priapism is effective. The value of CDU in distinguishing between ischemic and nonischemic priapism is also well recognized. In addition, CDU is useful for checking the patency of the shunt and assessing the hemodynamics to confirm the effective relief of veno-occlusive status. This is particularly important when the clinical resolution of priapism is not complete. The lack of complete resolution of priapism could be related to thrombosis of the cavernosal tissue, cavernosal hyperperfusion status after successful shunt surgery, or inadequate drainage of a shunt. With successful shunt surgery, we usually observe the restoration of cavernosal arterial flow. It is also useful for assessing the patency of the CD shunt after surgery. In 1 patient, the postoperative CDU showed no detectible blood flow; however, his CD shunt was patent. We believe that this lack of blood flow was due to cavernosal tissue damage rather than persistence of veno-occlusive pathophysiologic features. Thus, we did not perform additional surgery. It is difficult to check the patency of the cavernosal-glandular (Winter/Al-Ghorab) and cavernosal-spongiosal (Quackels) shunts using CDU. ${ }^{5}$

The potency outcome after shunt surgery has varied among reports. Nixon et al. ${ }^{1}$ reported that only 2 of 20 patients $(10 \%)$ with available follow-up had complete preservation of erectile function after shunt surgery. Three men (15\%) reported partial erection and 15 (75\%) had no erection at follow-up. ${ }^{1}$ In our series, even though previous shunt surgery by other urologists in many patients had failed, we observed an encouraging outcome of $69 \%$ of the patients having spontaneous erections after penile $C D$ shunt surgery. We believe that the widecaliber nature of the penile cavernosal-dorsal vein shunt using a saphenous vein graft might have contributed to the encouraging results. Furthermore, postoperative hyperemia might function as a repair mechanism for ischemic damage. Patients with a high cavernosal blood flow (PSV $\geq 20 \mathrm{~cm} / \mathrm{s}$ ) appeared to have good potency outcomes despite their duration of priapism, which lasted as long as 8 days.

This series included 1 patient with high-flow priapism resulting from perineal trauma. Shunt surgery is not a standard treatment option for high-flow priapism. However, this patient elected to undergo this procedure as an alternative treatment of cavernosal artery embolization, which has a risk of erectile dysfunction. After shunt surgery, he remained potent and sexually active for $>7$ years and had spontaneous closure of his arteriosinusoidal 
malformation about 7-7.5 years after surgery. At last follow-up, he required oral medication for his erectile dysfunction.

\section{CONCLUSIONS}

The penile CD shunt is effective in relieving priapism and has an encouraging rate of preservation for subsequent spontaneous erections. The advantages of this technique include wide and direct drainage of the corpora to pelvic veins, no risk of urethral complications, easy CDU assessment of shunt patency after surgery and femoral vein thrombosis, and easy access for constriction band compression or surgical ligation. In our experience, it appears to be effective in treating many patients with persistent priapism even after cavernosal-glandular or cavernosal-spongiosal shunts have failed.

\section{References}

1. Nixon RG, O'Connor JL, Milam DF. Efficacy of shunt surgery for refractory low flow priapism: a report on the incidence of failed detumescence and erectile dysfunction. J Urol. 2003;170:883886.

2. Chiou RK, Henslee DL, Anderson JC, et al. Colour Doppler ultrasonography assessment and a saphenous vein-graft penile venocorporeal shunt for priapism. BJU Int. 1999;83:138-139.
3. Chiou RK, Mues AC, Chiou CR, et al. Clinical experience and sexual function outcome of priapism patients treated with penile cavernosa-dorsal vein (CD) shunt using saphenous vein graft. Presented at the Sexual Medicine Society of North America Convention, Las Vegas, NV, November 2-5, 2006. J Sex Med. 2007;4(suppl 1): 76-77.

4. Rosen RC, Riley A, Wagner G, et al. The International Index of Erectile Function (IIEF): a multidimensional scale for assessment of erectile dysfunction. Urology. 1997;49:822-830.

5. Chiou RK, Broughton FL, Chiou CR, et al. Color Doppler ultrasound hemodynamic characteristics of priapism patients before and after therapy and its impact on subsequent penile shunt surgery. Presented at the Sexual Medicine Society of North America Convention, Las Vegas, NV, November 2-5, 2006. J Sex Med. 2007; 4(suppl 1):85.

6. Garrett RA, Rhamy DE. Priapism: management with corpus-saphenous shunt. J Urol. 1966;95:65-67.

7. Lue TF, Tanagho EA. Physiology of erection and pharmacological management of impotence. J Urol. 1987;137:829-836.

8. Lue TF, Pescatori ES. Distal cavernosum-glans shunts for ischemic priapism. J Sex Med. 2006;3:749-752.

9. Grayhack JT, McCullough W, O'Conor VJ Jr, et al. Venous bypass to control priapism. Invest Urol. 1964;1:509-513.

10. Kandel GL, Bender LI, Grove JS. Pulmonary embolism: a complication of corpus-saphenous shunt for priapism. J Urol. 1968;99:196197.

11. Carter RG, Thomas CE, Tomskey GC. Cavernospongiosum shunts in treatment of priapism. Urology. 1976;7:292-295.

12. Klugo RC, Olsson CA. Urethro cavernous fistula: complication of cavernospongiosal shunt. J Urol. 1972;108:750-751. 